\title{
Extracellular Biosynthesis of Copper and Copper Oxide Nanoparticles by Stereum hirsutum, a Native White-Rot Fungus from Chilean Forests
}

\author{
R. Cuevas, ${ }^{1,2}$ N. Durán, ${ }^{3}$ M. C. Diez, ${ }^{2,4}$ G. R. Tortella, ${ }^{2,4}$ and O. Rubilar ${ }^{2,4}$ \\ ${ }^{1}$ Doctoral Program of Science of Natural Resources, Universidad de La Frontera, Chile \\ ${ }^{2}$ Scientific and Technological Bioresource Nucleus, Instituto Química, Universidad de La Frontera, Chile \\ ${ }^{3}$ Biological Chemistry Laboratory, Instituto Química, Universidade Estadual de Campinas, SP, Brazil \\ ${ }^{4}$ Department of Chemical Engineering, Universidad de La Frontera, Chile
}

Correspondence should be addressed to O. Rubilar; olga.rubilar@ufrontera.cl

Received 29 July 2014; Revised 16 December 2014; Accepted 30 December 2014

Academic Editor: Ronen Hazan

Copyright (C) 2015 R. Cuevas et al. This is an open access article distributed under the Creative Commons Attribution License, which permits unrestricted use, distribution, and reproduction in any medium, provided the original work is properly cited.

\begin{abstract}
The white-rot fungus Stereum hirsutum was studied to evaluate its applicability for use in the biosynthesis of copper/copper oxide nanoparticles under different $\mathrm{pH}$ conditions and in the presence of three different copper salts $\left(\mathrm{CuCl}_{2}, \mathrm{CuSO}_{4}\right.$, and $\left.\mathrm{Cu}\left(\mathrm{NO}_{3}\right)_{2}\right)$. The nanoparticle formation was evaluated by UV-visible spectroscopy, electron microscopy (TEM), X-ray diffraction analysis (XRD), and Fourier transforms infrared spectroscopy (FTIR). The nanoparticles biosynthesis in presence of all copper salts demonstrated higher formation with $5 \mathrm{mM} \mathrm{CuCl}_{2}$ under alkaline conditions. TEM analysis confirmed that the nanoparticles were mainly spherical ( 5 to $20 \mathrm{~nm}$ ). The presence of amine groups attached to nanoparticles was confirmed by FTIR, which suggests that extracellular protein of fungus is responsible for the formation of the nanoparticles. Therefore, the white-rot fungus S. hirsutum was found to exhibit potential for use in the synthesis of copper/copper oxide nanoparticles.
\end{abstract}

\section{Introduction}

Nanoparticles have been synthesized through several physical and chemical processes; however, some chemical methods are costly and inefficient and generate hazardous wastes that are risky for the environment [1]. Therefore, there is an urgent need to develop environmentally friendly biological process for nanoparticle synthesis. In this context, the biosynthesis of stable metal nanoparticles by fungi has been reported $[2,3]$. Several studies [3-7] have demonstrated that the mechanism for the formation of metal nanoparticles involves the action of a large number of enzymes secreted by fungi.

Copper as a metal or copper oxides exhibit broadspectrum biocidal activity, and several studies during the last two years found that copper demonstrates remarkable antibacterial activity at the nanoscale [8-14]. In contrast to silver nanoparticles, which have been studied extensively for antibacterial application [5-7, 15-17], copper is an essential element for living organisms and may be suitable for biomedical applications [18]. It is important to note that copper is approximately 10 -fold cheaper than silver in the market, and therefore, a method utilizing copper would prove to be quite cost-effective [19]. On the other hand, it has been reported that copper nanoparticles are less toxic than silver nanoparticles [20].

Because Chile is one of the most important producers of copper in the world (http://copperinvestingnews.com/10581chiles-copper-production-to-rise-in-2012.html), this country exhibits great potential for the development of copper nanotechnology [18,21,22]. An important aspect in copper nanotechnology is the production of nanostructures through eco-friendly and safe processes. One of the processes that fulfil these requirements is the biogenic synthesis of nanostructures.

Microorganisms such as Fusarium oxysporum are able to leach copper from integrated circuits present on electronic boards under ambient conditions [23]. The analysis of the biogenic synthesis of copper oxides from $\mathrm{CuSO}_{4}$ by 
Penicillium aurantiogriseum, $P$. citrinum, $P$. waksmanii, and $F$. oxysporum showed no large polydispersity in the $\mathrm{pH}$ range of 5 to $9[24,25]$.

The development of technology that uses white-rot fungi for the production of metal nanoparticles is limited. At present, these studies have only investigated the production of gold and silver using the following different species of fungi such as Phanerochaete chrysosporium [2, 26], Pleurotus sajor-caju [27], Coriolus versicolor [28, 29], and Schizophyllum commune [30]. Due to the nonpathogenic nature of whiterot fungus, the application of these microorganisms for the production of metal nanoparticles could be seen an interesting alternative due to high biomass production and easy handling [2].

The synthesis has been reported mainly using plant extracts, such as soya [31], Aloe barbadensis Miller[32], and Tridax procumbens leaf extract [33]. In this context, a limited number of studies have been published, and these evaluated different fungal strains for the biosynthesis of copper nanoparticles. Fungi, such as Penicillium sp. and F. oxysporum strains, have been reported to biosynthesize copper oxide and $\mathrm{Cu}_{2} \mathrm{~S}$ nanoparticles $[24,25]$. The synthesis of copper or copper oxide nanoparticles can present different surface plasmon resonance, formed by the strong coupling between incident electromagnetic radiation and surface plasmons in metal nanoparticles [34]. In the case of copper nanoparticles the peak absorbance between 580 and $590 \mathrm{~nm}$ indicates formation of $\mathrm{Cu}$ nanoparticles [35], and the absorbance between 590 and $800 \mathrm{~nm}$ corresponds to copper oxides nanoparticles $[36,37]$. The use of copper or copper derivatives for the biosynthesis of nanoparticles using fungal strains has only been reported using $\mathrm{CuSO}_{4}$ copper salt, and no comparative studies have been performed using other copper salts, such as $\mathrm{CuCl}_{2}$ or $\mathrm{Cu}\left(\mathrm{NO}_{3}\right)_{2}$, with other fungal strains. Moreover, it is important to note that the biosynthesis of metal nanoparticles using different fungal extracts is really clean and environmentally friendly $[3,4,24]$. In addition, metals such as copper and biosynthesized copper nanoparticles have been shown to have better antimicrobial activity than nanoparticles synthesized via synthetic routes [38].

In this context, the aim of this study was to evaluate the ability to synthesize copper and copper oxide nanoparticles using a mycelium-free extract produced by Stereum hirsutum, a white-rot fungus, in the presence of three different copper salts and to characterize and assess the involvement of proteins in the formation of the nanoparticles.

\section{Materials and Methods}

2.1. Chemicals. $\mathrm{CuSO}_{4}, \mathrm{Cu}\left(\mathrm{NO}_{3}\right)_{2}$, and $\mathrm{CuCl}_{2}$ were used for the biosynthesis of $\mathrm{Cu}$ and copper oxide nanoparticles.

2.2. Microorganisms for the Biosynthesis of Nanoparticles. S. hirsutum, a native fungus from Southern Chilean forests, was obtained from the culture collection in the Environmental Biotechnology Laboratory of Universidad de La Frontera, Chile. The fungus was transferred from slant culture tubes (maintained at $4^{\circ} \mathrm{C}$ and subcultured every six months) to malt extract agar (MEA) plates and incubated at $30^{\circ} \mathrm{C}$ for $5-7$ days before being used for the inoculum preparation.

2.3. Preparation and Characterization of Mycelium-Free Fungal Extract. The fungal inoculums were obtained by transferring five circular pieces of agar (6 mm diameter) into $500 \mathrm{~mL}$ Erlenmeyer flasks with $100 \mathrm{~mL}$ of growth medium $(\mathrm{pH}$ 5.0) containing $15 \mathrm{~g} \mathrm{~L}^{-1}$ glucose, $5 \mathrm{~g} \mathrm{~L}^{-1}$ potato peptone, and $2.5 \mathrm{~g} \mathrm{~L}^{-1}$ yeast extract and incubating the culture in the dark for 15 days at $100 \mathrm{rpm}$ and $25^{\circ} \mathrm{C}$. The fungal biomass obtained at the end of the incubation period was filtered through filter paper grade 4 and washed thoroughly with sterilized deionized water. Approximately $8 \mathrm{~g}$ (wet weight) of the fungal biomass was then transferred into $100 \mathrm{~mL}$ Erlenmeyer flasks containing $50 \mathrm{~mL}$ of sterilized deionized water and incubated in an orbital shaker (100 rpm) for $24 \mathrm{~h}$ at $25^{\circ} \mathrm{C}$.

\subsection{Biosynthesis of Copper/Copper Oxide Nanoparticles}

2.4.1. Biosynthesis of Copper Nanoparticles by MyceliumFree Extract at Different $\mathrm{pH}$ Values. For the biosynthesis of copper and copper oxide nanoparticles, a volume of $50 \mathrm{~mL}$ of mycelium-free extract of $S$. hirsutum was transferred into $100 \mathrm{~mL}$ Erlenmeyer flasks, and the $\mathrm{pH}$ was adjusted to 5.0, 7.0, or 9.0. Then, $0.5 \mathrm{~mL}$ of a stock solution $(100 \mathrm{mM})$ of different copper salts, namely, $\mathrm{CuCl}_{2}, \mathrm{Cu}\left(\mathrm{NO}_{3}\right)_{2}$, and $\mathrm{CuSO}_{4}$, was added to obtain a final concentration of $5 \mathrm{mM}$. The flasks were incubated for 7 days on an orbital shaker $(100 \mathrm{rpm})$ at $25^{\circ} \mathrm{C}$ in the dark. Erlenmeyer flasks containing only the mycelium-free extract or the solution of $\mathrm{CuCl}_{2}, \mathrm{Cu}\left(\mathrm{NO}_{3}\right)_{2}$, and $\mathrm{CuSO}_{4}$ were established as controls. All of the assays were performed in triplicate.

A $2 \mathrm{~mL}$ aliquot was removed from each flask after $0,1,2$, 3 , 4, and 5 days of reaction, and their UV-visible spectra were obtained using a spectrophotometer Genesys 10S to confirm the biosynthesis of copper or copper oxide nanoparticles. The mycelium-free extract that resulted in the reaction product that exhibited a higher peak area and a greater height in its UV-visible spectrum was selected for further studies. The peak absorbance between 580 and $590 \mathrm{~nm}$ corresponded to $\mathrm{Cu}$ nanoparticles [35], and the absorbance between 590 and $800 \mathrm{~nm}$ corresponded to copper oxides $[36,37]$.

2.5. Characterization of Copper Nanoparticles. The copper or copper oxide nanoparticles obtained from the mycelium-free extract selected as described above were characterized using a transmission electron microscope (TEM) model JEOL JEM 1200EX II and through Fourier transformed infrared (FTIR) spectroscopy using a CARY 630 FTIR Agilent Technologies instrument. Furthermore, the particle size distribution and zeta potential of the samples were obtained through Zetasizer Nano ZS90 X-ray diffraction (XRD) analyses using a Shimadzu XRD 7000 instrument.

\section{Results and Discussion}

3.1. Biosynthesis of Copper and Copper Oxide Nanoparticles by Mycelium-Free Extract at Different $p H$ Values. Table 1 shows the results obtained by UV-visible spectrum for 
TABLE 1: Maximum absorbance on plasmon resonance absorption (SPR) of the copper or copper oxide nanoparticles produced at $25^{\circ} \mathrm{C}$ after 2 and $5 \mathrm{~d}$ of reaction: effect of $\mathrm{pH}$ and salts $(5 \mathrm{mM})$.

\begin{tabular}{cccc}
\hline $\mathrm{pH}$ & Salts & $\begin{array}{c}\text { Absorbance } \\
(2 \mathrm{~d})(\lambda, \mathrm{nm})\end{array}$ & $\begin{array}{c}\text { Absorbance } \\
(5 \mathrm{~d})(\lambda, \mathrm{nm})\end{array}$ \\
\hline \multirow{3}{*}{5} & $\mathrm{CuCl}_{2}$ & $0.03 \pm 0.004(670)$ & $0.04 \pm 0.005(670)$ \\
& $\mathrm{Cu}\left(\mathrm{NO}_{3}\right)_{2}$ & $0.02 \pm 0.003(670)$ & $0.02 \pm 0.002(670)$ \\
& $\mathrm{CuSO}_{4}$ & $0.01 \pm 0.003(670)$ & $0.02 \pm 0.003(670)$ \\
\hline & $\mathrm{CuCl}_{2}$ & $0.03 \pm 0.003(620)$ & $0.04 \pm 0.002(620)$ \\
7 & $\mathrm{Cu}\left(\mathrm{NO}_{3}\right)_{2}$ & $0.04 \pm 0.004(670)$ & $0.04 \pm 0.003(670)$ \\
& $\mathrm{CuSO}_{4}$ & $0.02 \pm 0.003(670)$ & $0.03 \pm 0.002(670)$ \\
\hline & $\mathrm{CuCl}_{2}$ & $0.03 \pm 0.002(620)$ & $0.06 \pm 0.004(620)$ \\
9 & ${\mathrm{Cu}\left(\mathrm{NO}_{3}\right)_{2}}$ & $0.03 \pm 0.003(670)$ & $0.06 \pm 0.004(670)$ \\
& $\mathrm{CuSO}_{4}$ & $0.02 \pm 0.002(670)$ & $0.04 \pm 0.003(670-710)$ \\
\hline
\end{tabular}

the biosynthesis of copper or copper oxide nanoparticles by the mycelium-free extract of $S$. hirsutum in presence of $5 \mathrm{mM}$ of different copper salts $\left(\mathrm{CuCL}_{2}, \mathrm{Cu}\left(\mathrm{NO}_{3}\right)_{2}\right.$ or $\left.\mathrm{CuSO}_{4}\right)$ and different $\mathrm{pH}$ values $(5.0,7.9$, and 9.0).

As shown in Table 1, surface-plasmon resonance band was observed between 620 to $710 \mathrm{~nm}$ with the three copper salts evaluated. After $50 \mathrm{~h}$ of reaction at $\mathrm{pH}$ 5.0, a maximum absorbance at $670 \mathrm{~nm}$ was observed with the three copper salts evaluated. At $\mathrm{pH} 7$, a maximum absorbance at $670 \mathrm{~nm}$ was obtained with $\mathrm{Cu}\left(\mathrm{NO}_{3}\right)_{2}$ and $\mathrm{CuSO}_{4}$, but a change in the maximum absorbance peak was observed $(620 \mathrm{~nm})$ when $\mathrm{CuCl}_{2}$ was used as the substrate. In contrast, higher absorbance values at 620 and $670 \mathrm{~nm}$ were obtained with $\mathrm{CuCl}_{2}$ and $\mathrm{Cu}\left(\mathrm{NO}_{3}\right)_{2}$, respectively, after $3 \mathrm{~d}$ of reaction at $\mathrm{pH}$ 9.0.

The biosynthesis of copper or copper oxide nanoparticles is readily apparent visually due to colour variations in the mycelium-free extract of $S$. hirsutum compared with the colour of the extract without copper salts. After $5 \mathrm{~d}$ of reaction at $\mathrm{pH} 9$, the addition of $\mathrm{CuCl}_{2}$ as the substrate to the mycelium-free extract of $S$. hirsutum resulted in the formation of bluish solution, and the surface of the nanoparticles was surrounded by a biopolymer. However, even after exhaustive washes, it was not possible to achieve an effective separation or release of this polymer from the nanoparticles. In contrast, as shown in Figure 1, the progressive appearance of a strong broadening of the plasmon resonance between 590 to $650 \mathrm{~nm}$ and the peak maximum at $620 \mathrm{~nm}$ was observed, indicating the biosynthesis of copper oxide nanoparticles with a small particle size [36, 37], as was confirmed by TEM (shown below). In general, it has been reported that copper nanoparticles display a surface plasmon peak at 580-590 [35]. However, red shifts in absorption can occur between 590 and $800 \mathrm{~nm}$, which are characteristic absorption peaks for cuprous oxide $\left(\mathrm{Cu}_{2} \mathrm{O}\right)$ nanoparticles $[36,37]$.

Moreover, the precise position of the SPR band could differ depending on the size, shape, and capping agent, among other individual properties of the nanoparticles [39]. According to the results obtained by the UV-visible spectra, fungal extract at $\mathrm{pH} 9.0$ and $5 \mathrm{mM}$ of $\mathrm{CuCl}_{2}$ (Figure 1) not showed the typical resonance plasmon at $590 \mathrm{~nm}$ after $5 \mathrm{~h}$ of reaction,

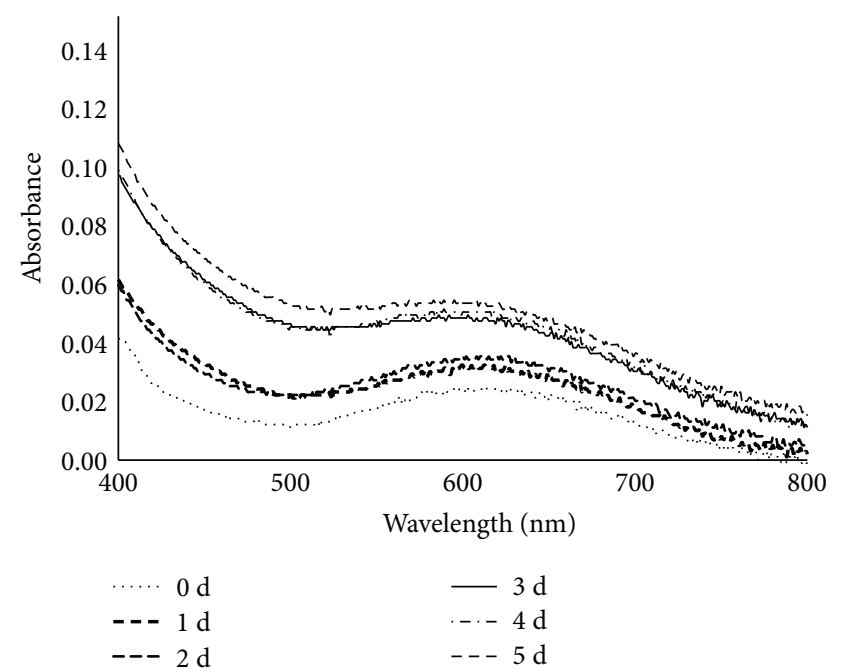

FIGURE 1: Biosynthesis of copper and copper oxide nanoparticles mediated by the mycelium-free extract of $S$. hirsutum over a 5-day reaction period at $\mathrm{pH} 9.0$ in the presence of $\mathrm{CuCl}_{2}(5 \mathrm{mM})$. Kinetics of the absorbance on resonance plasmon absorption (SPR) based on the UV-visible spectrum of copper or copper oxide nanoparticles.

indicating the absence of zero-valent copper nanoparticles $(\mathrm{CuO})$ or the presence of a minimal concentration of these. In this case, at $\mathrm{pH} \mathrm{9,} \mathrm{the} \mathrm{copper} \mathrm{nanoparticles} \mathrm{were} \mathrm{likely}$ formed within a short period, resulting in the production of $\mathrm{Cu}_{2} \mathrm{O}$. In the presence of $\mathrm{Cu}\left(\mathrm{NO}_{3}\right)_{2}$, the analysis of the UV-visible spectra showed that the surface plasmon peak at $670 \mathrm{~nm}$ is found at all $\mathrm{pH}$ values evaluated, which likely indicates the formation of cupric oxide $(\mathrm{CuO})$ nanoparticles, as was reported by Abboud et al. [17] and Phuo and Chyu [40]. However, other researchers have reported that the synthesis of $\mathrm{CuO}$ nanoparticles can be monitored by the formation of SPR between 250 and $300 \mathrm{~nm}$ [17]. However, these differences may be attributed to the differences in the methods used (chemical or biological) for the synthesis of the nanoparticles. Similarly, it has been reported that cuprous oxide $\left(\mathrm{Cu}_{2} \mathrm{O}\right)$ can be monitored through its UV-visible spectra based on the formation of a SPR band between 250 and $300 \mathrm{~nm}$. Therefore, the synthesis/biosynthesis of copper or copper oxide nanoparticles cannot be monitored only through their UV-visible spectra, and other identification techniques, such as FTIR and XRD, are necessary.

The addition of $5 \mathrm{mM} \mathrm{CuCl}_{2}$ to mycelium-free extract of $\mathrm{S}$. hirsutum at $\mathrm{pH} 9$ and $25^{\circ} \mathrm{C}$ resulted in the formation of nanoparticles after 5 days, and these were embedded in a biopolymer. After exhaustive washes, it was not possible to achieve an effective separation or release this polymer from the nanoparticles. The characteristics are shown in Figure 2.

3.2. Nanoparticles Characterization. The characterization of the nanoparticles focused on the analysis of the copper nanoparticles biosynthesized using $\mathrm{CuCl}_{2}$ because more defined peaks were obtained with this salt.

Figure 2 shows the transmission electron micrograph (TEM) results. In particular, Figure 2(a) shows the TEM image of the copper or copper oxide nanoparticles 


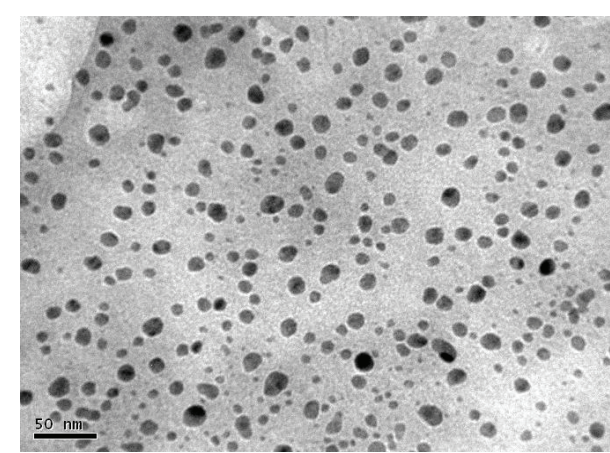

(a)

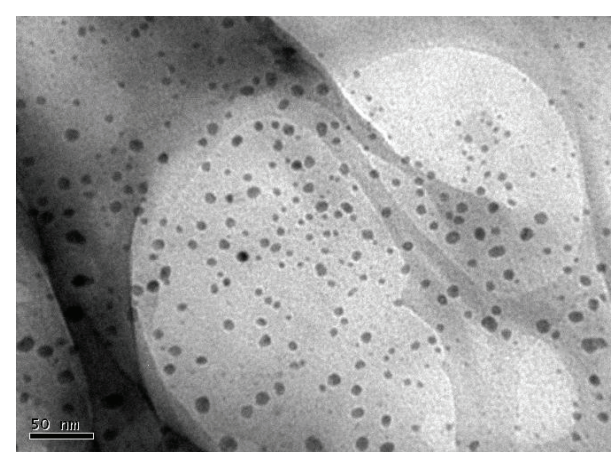

(b)

FIgURE 2: Transmission electron microscopy (TEMs) of (a) copper and/or copper oxide nanoparticles and (b) the nanoparticles embedded in the polymer. These nanoparticles were biosynthesized by the mycelium-free extract of $S$. hirsutum in the presence of $\mathrm{CuCl}_{2}(5 \mathrm{mM})$ after $3 \mathrm{~d}$ at $\mathrm{pH} 9.0$.

synthesized with the mycelium-free extract of S. hirsutum. It is clear that the nanoparticles exhibit a spherical shape, monodispersity, and diameters between 5 and $20 \mathrm{~nm}$. In addition, Figure 2(b) shows a TEM image of the nanoparticles embedded in the polymer.

Figure 3 shows the results of the FTIR, XRD, and zeta potential analyses of the nanoparticles biosynthesized using $\mathrm{CuCl}_{2}$ at $\mathrm{pH} 9.0$ after $72 \mathrm{~h}$ of reaction. The FTIR spectra (Figure 3(a)) of the nanoparticles biosynthesized at $\mathrm{pH} 9.0$ revealed bands in the regions of $3280 \mathrm{~cm}^{-1}$ and $2924 \mathrm{~cm}^{-1}$, which are reported as type movements of stretching vibrations in primary and secondary amines [2, 30, 41]. Other researchers reported bands at $1640 \mathrm{~cm}^{-1}$ and $1540 \mathrm{~cm}^{-1}$, which are associated with type movements corresponding to bending vibrations $[2,42,43]$. The bands near $1029 \mathrm{~cm}^{-1}$ are reported to be $\mathrm{C}-\mathrm{N}$ stretching vibrations of aromatic and aliphatic amines [43], and another band of interest found in this study was observed at 1243 and $1244 \mathrm{~cm}^{-1}$, which is designated for bending vibration movements in amides I and amides III [25]. A band at $1076 \mathrm{~cm}^{-1}$, which corresponds to bending vibration movements in amides II, was reported by Hosseini et al. [25] for the synthesis of CuS nanoparticles; moreover, Chan and Mashitah [30] reported the same band in the synthesis of silver nanoparticles biosynthesized by whiterot fungi.

The overall observations confirm the presence of protein in the samples of silver nanoparticles and copper and copper oxide nanoparticles. This evidence suggests that the release of extracellular protein by white-rot fungi may have resulted in the formation and stabilization of the nanoparticles biosynthesized in aqueous medium $[2,42,43]$.

The bands at the $900-1105 \mathrm{~cm}^{-1}$ region may also indicate $\mathrm{C}-\mathrm{O}-\mathrm{C}$ pyranose ring stretching, beta-glycosidic linkages, and glycosidic ethers bands of some polycarbohydrates. These main bands indicate the presence of protein on the surface of the copper and copper oxide nanoparticles, as well as some biopolymers, likely polycarbohydrate.

An XRD analysis was performed (Figure 3(b)), and the sample produced by Stereum hirsutum showed a powder Xray diffractometry pattern with peaks at $43.6^{\circ}, 50.7^{\circ}$, and $74.45^{\circ}$, which represent the [111], [200], and [220] planes of the FCC structure of copper [44] and peaks at $29.4^{\circ}, 36.8^{\circ}$, $42.1^{\circ}, 61.9^{\circ}$, and $77.6^{\circ}$, which represent the [110], [111], [200], [220], and [222] plants of the $\mathrm{Cu}_{2} \mathrm{O}$ structure (JCPDS file number $05-0667)[45,46]$. The peaks at $32.8^{\circ}, 35.9^{\circ}, 39.1^{\circ}$, $46.3^{\circ}, 49.1^{\circ}, 52.9^{\circ}, 58.7^{\circ}, 66.6^{\circ}, 68.3^{\circ}, 72.6^{\circ}$, and $75.5^{\circ}$ can be assigned to the [-111], [002], [111], [-112], [-202], [020], [202], [-311], [113], [311], and [400] planes, which match the values of monoclinic-phase $\mathrm{CuO}$ reported in the literature (JCPDS file number 45-0937) [47].

Therefore, the formation of $\mathrm{Cu}^{0}, \mathrm{Cu}_{2} \mathrm{O}$, and $\mathrm{CuO}$ nanocrystals in the sample was confirmed by the abovedescribed XRD studies, similarly to the transformation of copper ions by soil microorganisms [48]. In addition, these samples exhibited a peak with a $2 \theta$ of approximately $16.5^{\circ}$, $22.5^{\circ}$, and probably $34.6^{\circ}$, representing the [110], [200], and [004] crystal patterns, which is hypothesized to represent the typical cellulose nanofibers structure. In fact, the cellulose crystals exhibit characteristic assignments of [110], [200], and [004] planes [49]. It is likely that these peaks indicate that the biopolymer formed in the nanoparticles is a polycarbohydrate and that these also involved the protein found in the surface-capped nanoparticles. As shown in Figure 3(c), the zeta potential results of the nanoparticles embedded in the biopolymer present a negative surface charge with a value of approximately $-2 \mathrm{mV}$. The antimicrobial activities of this new biomaterial are under study.

\section{Final Remarks}

We have demonstrated that the use of the mycelium-free extract of $S$. hirsutum is an efficient tool for the biosynthesis of copper nanoparticles, particularly in the presence of $\mathrm{CuCl}_{2}$ and under neutral or basic conditions. The TEM results revealed that the biosynthesized nanoparticles were monodispersed, spherical, and between 4 and $5 \mathrm{~nm}$ in size. The UV-visible spectra demonstrated that the biosynthesized nanoparticles exhibited different oxidation states; therefore, a mixture of zero-valent copper $\left(\mathrm{Cu}^{0}\right)$, cupric oxide $(\mathrm{CuO})$, and cuprous oxide nanoparticles was synthesized by the mycelium-free extract of $S$. hirsutum. These observations 


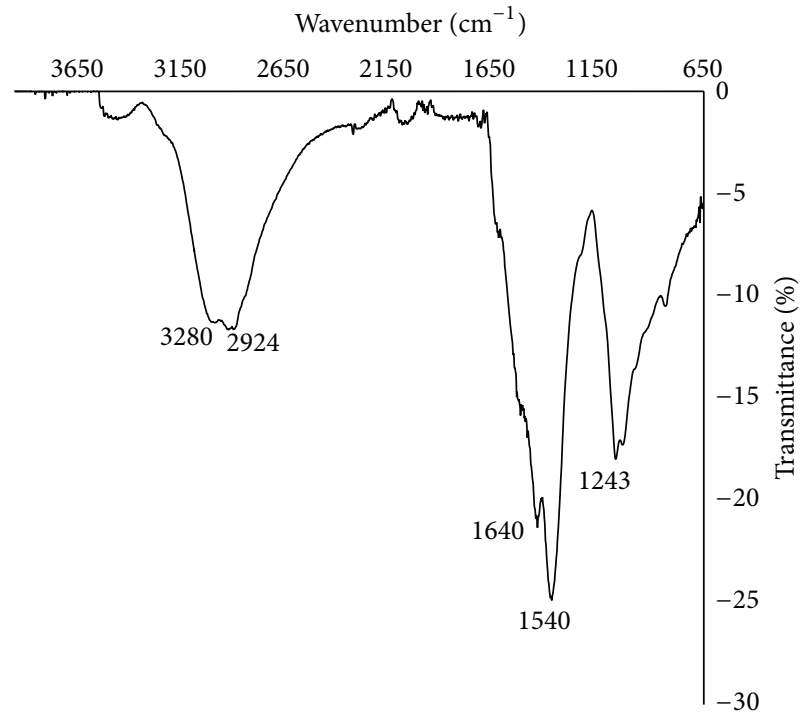

(a)

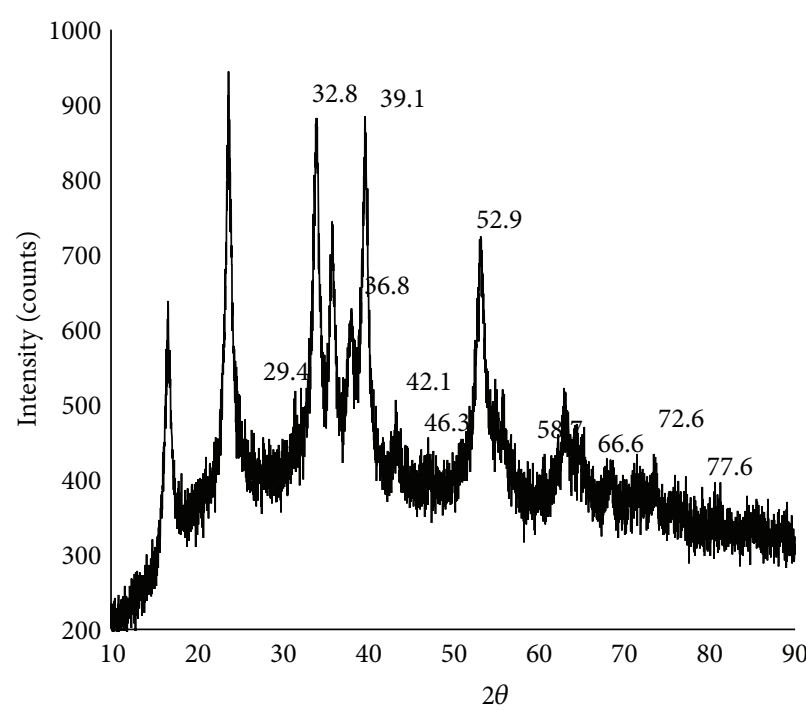

(b)

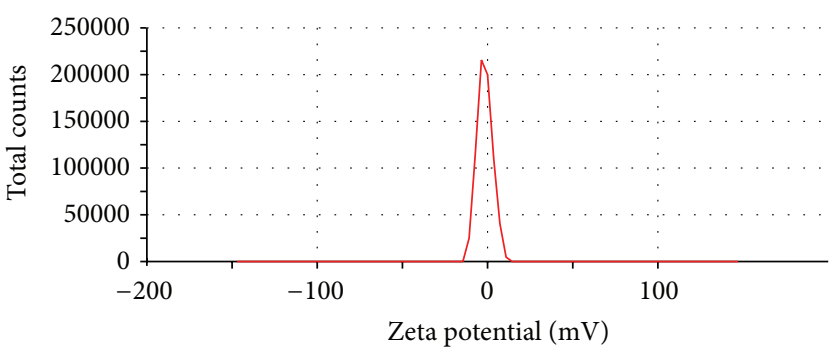

(c)

Figure 3: Analysis of the copper and/or copper oxide nanoparticles biosynthesized by the mycelium-free extract of $S$. hirsutum after $5 \mathrm{~d}$ of reaction at $\mathrm{pH} 9.0$ in the presence of $\mathrm{CuCl}_{2}(5 \mathrm{mM}$ ). (a) FTIR spectra, (b) XRD pattern, and (c) zeta potential.

were confirmed by XRD analysis, which also revealed that a polycarbohydrate is associated with the stability of the nanoparticle. The presence of protein attached to the copper and copper oxide nanoparticles was confirmed by FTIR, which suggests that the release of extracellular protein by $S$. hirsutum may result in the formation and stabilization of the nanoparticles biosynthesized in aqueous medium. In addition, this technique demonstrated the presence of polycarbohydrates in the copper and copper oxide nanoparticles. Therefore, this method provides a simple, fast, and efficient tool for the green synthesis of copper and copper oxide nanoparticles.

Finally, it is important to study the toxicity of copper nanoparticles biosynthesized by this green method, especially because cytotoxicity of copper nanoparticles is very poorly understood compared to gold or silver nanoparticles. In this sense, although bacteria have been demonstrated to be sensitive microorganisms, a wide range of metal nanoparticles, other species as crustaceans, algae, and fish, have been shown to be more sensitive to metal nanoparticles [20].

\section{Conflict of Interests}

The authors declare that there is no conflict of interests regarding the publication of this paper.

\section{Acknowledgments}

The support provided by FONDECYT Project 1130854, CONICYT Scholarship 21110491, DIUFRO DI14-1003, CRHIAM/CONICYT/FONDAP15130015 and by FAPESP, CNPq, INOMAT (MCTI/CNPq), Network of Brazilian Nanotoxicology (MCTI/CNPq), and NanoBioss (MCTI) Brazil is also acknowledged. The authors appreciate the support provided by the Research Group of Environmental Biotechnology.

\section{References}

[1] X. Zhang, S. Yan, R. D. Tyagi, and R. Y. Surampalli, "Synthesis of nanoparticles by microorganisms and their application in enhancing microbiological reaction rates," Chemosphere, vol. 82, no. 4, pp. 489-494, 2011.

[2] N. Vigneshwaran, N. M. Ashtaputre, P. V. Varadarajan, R. P. Nachane, K. M. Paralikar, and R. H. Balasubramanya, "Biological synthesis of silver nanoparticles using the fungus Aspergillus flavus," Materials Letters, vol. 61, no. 6, pp. 1413-1418, 2007.

[3] N. Durán, P. D. Marcato, O. L. Alves, G. I. H. de Souza, and E. Esposito, "Mechanistic aspects of biosynthesis of silver nanoparticles by several Fusarium oxysporum strains," Journal of Nanobiotechnology, vol. 3, article 8, 2005. 
[4] A. Ahmad, P. Mukherjee, S. Senapati et al., "Extracellular biosynthesis of silver nanoparticles using the fungus Fusarium oxysporum," Colloids and Surfaces B: Biointerfaces, vol. 28, no. 4, pp. 313-318, 2003.

[5] N. Durán, P. D. Marcato, R. de Conti, O. L. Alves, F. T. M. Costa, and M. Brocchi, "Potential use of silver nanoparticles on pathogenic bacteria, their toxicity and possible mechanisms of action," Journal of the Brazilian Chemical Society, vol. 21, no. 6, pp. 949-959, 2010.

[6] N. Durán, P. D. Marcato, A. Ingle, A. Gade, and M. Ra, "Fungi mediated synthesis of silver nanoparticles: characterization processes and applications," in Progress in Mycology, M. Rai and G. Kövics, Eds., chapter 342, pp. 425-449, Scientific Publishers, Jodhpur, India, 2010.

[7] N. Durán, P. D. Marcato, M. Durán, A. Yadav, A. Gade, and M. Rai, "Mechanistic aspects in the biogenic synthesis of extracellular metal nanoparticles by peptides, bacteria, fungi, and plants," Applied Microbiology and Biotechnology, vol. 90, no. 5, pp. 1609-1624, 2011.

[8] M. Raffi, S. Mehrwan, T. M. Bhatti et al., "Investigations into the antibacterial behavior of copper nanoparticles against Escherichia coli," Annals of Microbiology, vol. 60, no. 1, pp. 75-80, 2010.

[9] A. Mikolay, S. Huggett, L. Tikana, G. Grass, J. Braun, and D. H. Nies, "Survival of bacteria on metallic copper surfaces in a hospital trial," Applied Microbiology and Biotechnology, vol. 87, no. 5, pp. 1875-1879, 2010.

[10] N. C. Cady, J. L. Behnke, and A. D. Strickland, "Copper-based nanostructured coatings on natural cellulose: nanocomposites exhibiting rapid and efficient inhibition of a multi-drug resistant wound pathogen, A. baumannii, and mammalian cell biocompatibility in vitro," Advanced Functional Materials, vol. 21, no. 13, pp. 2506-2514, 2011.

[11] A. K. Chatterjee, R. K. Sarkar, A. P. Chattopadhyay, P. Aich, R. Chakraborty, and T. Basu, "A simple robust method for synthesis of metallic copper nanoparticles of high antibacterial potency against E. coli," Nanotechnology, vol. 23, no. 8, Article ID 085103, 2012.

[12] N. Durán and A. B. Seabra, "Metallic oxide nanoparticles: state of the art in biogenic syntheses and their mechanisms," Applied Microbiology and Biotechnology, vol. 95, no. 2, pp. 275-288, 2012.

[13] D. Longano, N. Ditaranto, L. Sabbatini, L. Torsi, and N. Cioffi, "Synthesis and antimicrobial activity of copper nanomaterials," in Nano-Antimicrobials: Progress and Prospects, N. Cioffi and M. Rai, Eds., chapter 3, pp. 85-117, Springer, New York, NY, USA, 2012.

[14] L. C. Giannossa, D. Longano, N. Ditaranto et al., "Metal nanoantimicrobials for textile applications," Nanotechnology Reviews, vol. 2, no. 3, pp. 307-331, 2013.

[15] H. J. Lee, G. Lee, N. R. Jang, J. H. Yun, J. Y. Song, and B. S. Kim, "Biological synthesis of copper nanoparticles using plant extract," Nanotechnology, vol. 1, pp. 371-374, 2011.

[16] N. Durán and P. D. Marcato, "Biotechnological routes to metallic nanoparticles production: mechanistics aspects, antimicrobial activity, toxicity and industrial applications," in NanoAntimicrobials: Progress and Prospects, M. Rai and N. Cioffi, Eds., chapter 3, pp. 337-374, Springer, Berlin, Germany, 2012.

[17] Y. Abboud, T. Saffaj, A. Chagraoui et al., "Biosynthesis, characterization and antimicrobial activity of copper oxide nanoparticles (CONPs) produced using brown alga extract (Bifurcaria bifurcata)," Applied Nanoscience, vol. 4, pp. 571-576, 2014.
[18] O. Rubilar, M. Rai, G. Tortella, M. C. Diez, A. B. Seabra, and N. Durán, "Biogenic nanoparticles: copper, copper oxides, copper sulphides, complex copper nanostructures and their applications," Biotechnology Letters, vol. 35, no. 9, pp. 1365-1375, 2013.

[19] B. Jia, Y. Mei, L. Cheng, J. Zhou, and L. Zhang, "Preparation of copper nanoparticles coated cellulose films with antibacterial properties through one-step reduction," ACS Applied Materials and Interfaces, vol. 4, no. 6, pp. 2897-2902, 2012.

[20] O. Bondarenko, K. Juganson, A. Ivask, K. Kasemets, M. Mortimer, and A. Kahru, "Toxicity of $\mathrm{Ag}, \mathrm{CuO}$ and $\mathrm{ZnO}$ nanoparticles to selected environmentally relevant test organisms and mammalian cells in vitro: a critical review," Archives of Toxicology, vol. 87, no. 7, pp. 1181-1200, 2013.

[21] P. Kanhed, S. Birla, S. Gaikwad et al., "In vitro antifungal efficacy of copper nanoparticles against selected crop pathogenic fungi," Materials Letters, vol. 115, pp. 13-17, 2014.

[22] M. Rai, A. Ingle, I. Gupta et al., "Cytotoxicity and genotoxicity of copper nanoparticles," in Nanotoxicology: Materials, and Assessments, N. Durán, S. S. Guterres, and O. L. Alves, Eds., chapter 15, pp. 325-345, Springer, Berlin, Germany, 2014.

[23] D. R. Majumder, "Bioremediation: copper nanoparticles from electronic-waste," International Journal of Engineering Science and Technology, vol. 4, no. 10, pp. 4380-4389, 2012.

[24] S. Honary, H. Barabadi, E. Gharaei-Fathabad, and F. Naghibi, "Green synthesis of copper oxide nanoparticles using Penicillium aurantiogriseum, Penicillium citrinum and Penicillium waksmani," Digest Journal of Nanomaterials and Biostructures, vol. 7, no. 3, pp. 999-1005, 2012.

[25] M. R. Hosseini, M. Schaffie, M. Pazouki, E. Darezereshki, and M. Ranjbar, "Biologically synthesized copper sulfide nanoparticles: production and characterization," Materials Science in Semiconductor Processing, vol. 15, no. 2, pp. 222-225, 2012.

[26] R. Sanghi, P. Verma, and S. Puri, "Enzymatic formation of gold nanoparticles using Phanerochaete chrysosporium," Advances in Chemical Engineering and Science, vol. 1, no. 3, pp. 154-162, 2011.

[27] R. Nithya and R. Ragunathan, "Synthesis of silver nanoparticle using Pleurotus sajor caju and its antimicrobial study," Digest Journal of Nanomaterials and Biostructures, vol. 4, no. 4, pp. 623-629, 2009.

[28] R. Sanghi and P. Verma, "Biomimetic synthesis and characterisation of protein capped silver nanoparticles," Bioresource Technology, vol. 100, no. 1, pp. 501-504, 2009.

[29] R. Sanghi and P. Verma, "A facile green extracellular biosynthesis of CdS nanoparticles by immobilized fungus," Chemical Engineering Journal, vol. 155, no. 3, pp. 886-891, 2009.

[30] Y. S. Chan and M. D. Mashitah, "Biosynthesis of silver nanoparticles from Schizophyllum commune and in-vitro antibacterial and antifungal activity studies," Journal of Physical Science, vol. 24, no. 2, pp. 83-96, 2013.

[31] M. J. Guajardo-Pacheco, J. E. Morales-Sánchez, J. GonzálezHernández, and F. Ruiz, "Synthesis of copper nanoparticles using soybeans as a chelant agent," Materials Letters, vol. 64, no. 12, pp. 1361-1364, 2010.

[32] S. Gunalan, R. Sivaraj, and R. Venckatesh, "Aloe barbadensis Miller mediated green synthesis of mono-disperse copper oxide nanoparticles: optical properties," Spectrochimica Acta Part A: Molecular and Biomolecular Spectroscopy, vol. 97, pp. 1140-1144, 2012.

[33] K. Gopalakrishsnan, C. Ramesh, V. Ragunathan, and M. Thamailselvan, "Antibacterial activity of $\mathrm{Cu}_{2} \mathrm{O}$ nanoparticles on 
E. coli synthesized from Tridax procumbens leaf extract and surface coating with polyaniline," Digest Journal of Nanomaterials and Biostructures, vol. 7, no. 2, pp. 833-839, 2012.

[34] C. Noguez, "Surface plasmons on metal nanoparticles: the influence of shape and physical environment," The Journal of Physical Chemistry C, vol. 111, no. 10, pp. 3606-3619, 2007.

[35] R. A. Soomro, S. T. Hussain Sherazi, N. Memon et al., "Synthesis of air stable copper nanoparticles and their use in catalysis," Advanced Materials Letters, vol. 5, no. 4, pp. 191-198, 2014.

[36] I. Lisiecki and M. P. Pileni, "Copper metallic particles synthesized 'in situ' in reverse micelles: influence of various parameters on the size of the particles," Journal of Physical Chemistry, vol. 99, no. 14, pp. 5077-5082, 1995.

[37] S. Banerjee and D. Chakravorty, "Optical absorption by nanoparticles of $\mathrm{Cu}_{2} \mathrm{O}$," Europhysics Letters, vol. 52, no. 4, pp. 468-473, 2000.

[38] H.-J. Lee, J. Y. Song, and B. S. Kim, "Biological synthesis of copper nanoparticles using Magnolia kobus leaf extract and their antibacterial activity," Journal of Chemical Technology and Biotechnology, vol. 88, no. 11, pp. 1971-1977, 2013.

[39] D. Mott, J. Luo, A. Smith, P. N. Njoki, L. Wang, and C.-J. Zhong, "Nanocrystal and surface alloy properties of bimetallic GoldPlatinum nanoparticles," Nanoscale Research Letters, vol. 2, no. 1, pp. 12-16, 2007.

[40] T. X. Phuo and M. K. Chyu, "Synthesis and characterization of nanocomposites using the nanoscale laser soldering in liquid technique," Journal of Nanoscience and Nanotechnology, vol. 1, p. 101, 2013.

[41] A. Gade, S. Gaikwad, N. Duran, and M. Rai, "Green synthesis of silver nanoparticles by Phoma glomerata," Micron, vol. 59, pp. 52-59, 2014.

[42] S. Basavaraja, S. D. Balaji, A. Lagashetty, A. H. Rajasab, and A. Venkataraman, "Extracellular biosynthesis of silver nanoparticles using the fungus Fusarium semitectum," Materials Research Bulletin, vol. 43, no. 5, pp. 1164-1170, 2008.

[43] N. S. Shaligram, M. Bule, R. Bhambure et al., "Biosynthesis of silver nanoparticles using aqueous extract from the compactin producing fungal strain," Process Biochemistry, vol. 44, no. 8, pp. 939-943, 2009.

[44] B. K. Park, S. Jeong, D. Kim, J. Moon, S. Lim, and J. S. Kim, "Synthesis and size control of monodisperse copper nanoparticles by polyol method," Journal of Colloid and Interface Science, vol. 311, no. 2, pp. 417-424, 2007.

[45] M. Kooti and L. Matouri, "Fabrication of nanosized cuprous oxide using fehling's solution," Scientia Iranica, vol. 17, pp. 7378, 2010.

[46] M. Srivastava, J. Singh, R. K. Mishra, and A. K. Ojha, "Electrooptical and magnetic properties of monodispersed colloidal $\mathrm{Cu}_{2} \mathrm{O}$ nanoparticles," Journal of Alloys and Compounds, vol. 555, pp. 123-130, 2013.

[47] D. P. Volanti, D. Keyson, L. S. Cavalcante et al., "Synthesis and characterization of $\mathrm{CuO}$ flower-nanostructure processing by a domestic hydrothermal microwave," Journal of Alloys and Compounds, vol. 459, no. 1-2, pp. 537-542, 2008.

[48] D. Collins, T. Luxton, N. Kumar, S. Shah, V. K. Walker, and V. Shah, "Assessing the impact of copper and zinc oxide nanoparticles on soil: a field study," PLOS ONE, vol. 7, no. 8, Article ID e42663, 2012.

[49] A. Kumar, Y. S. Negi, V. Choudhary, and N. K. Bhardwaj, "Characterization of cellulose nanocrystals produced by acidhydrolysis from sugarcane bagasse as agro-waste," Journal of Materials Physics and Chemistry, vol. 2, no. 1, pp. 1-8, 2014. 

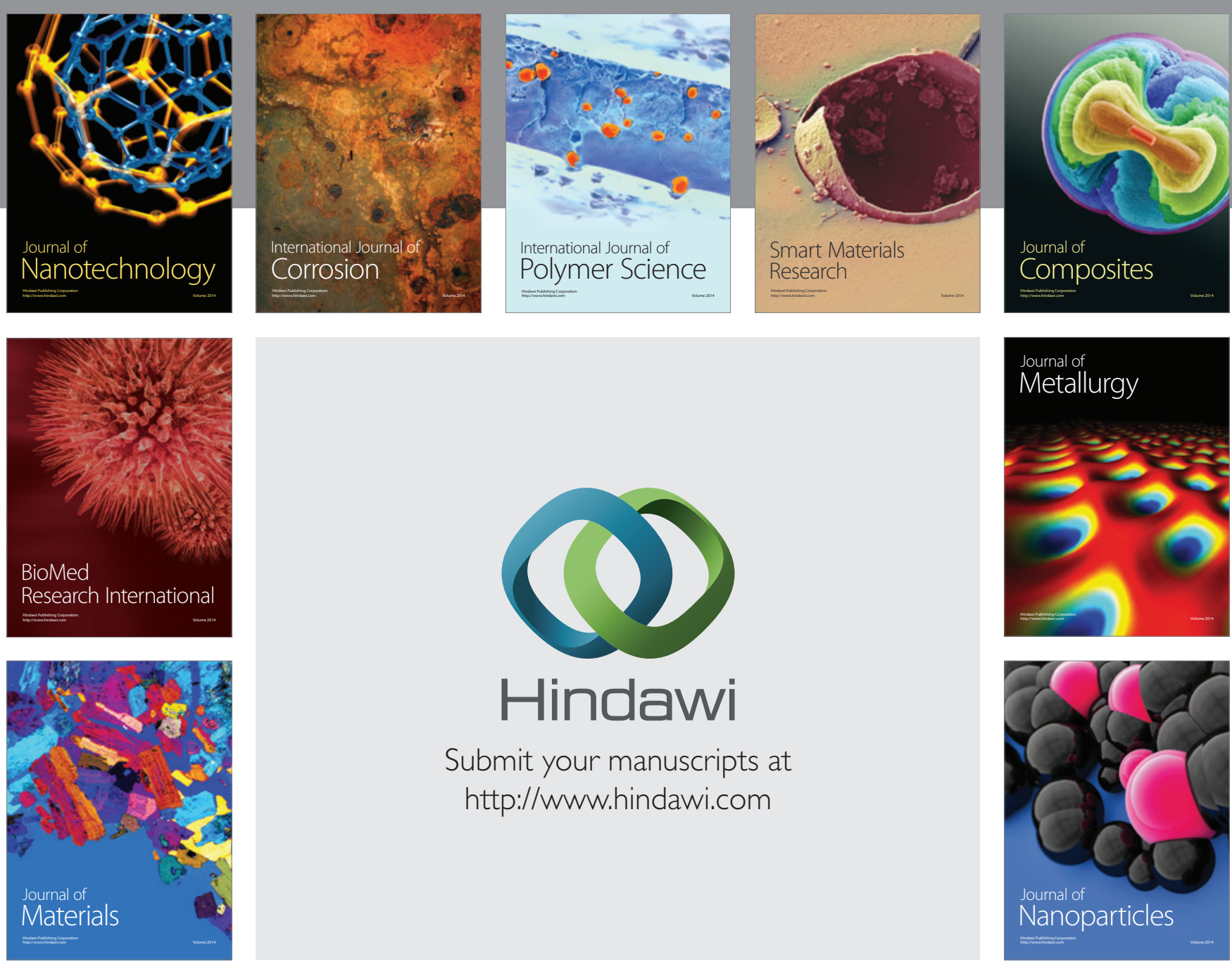

Submit your manuscripts at http://www.hindawi.com
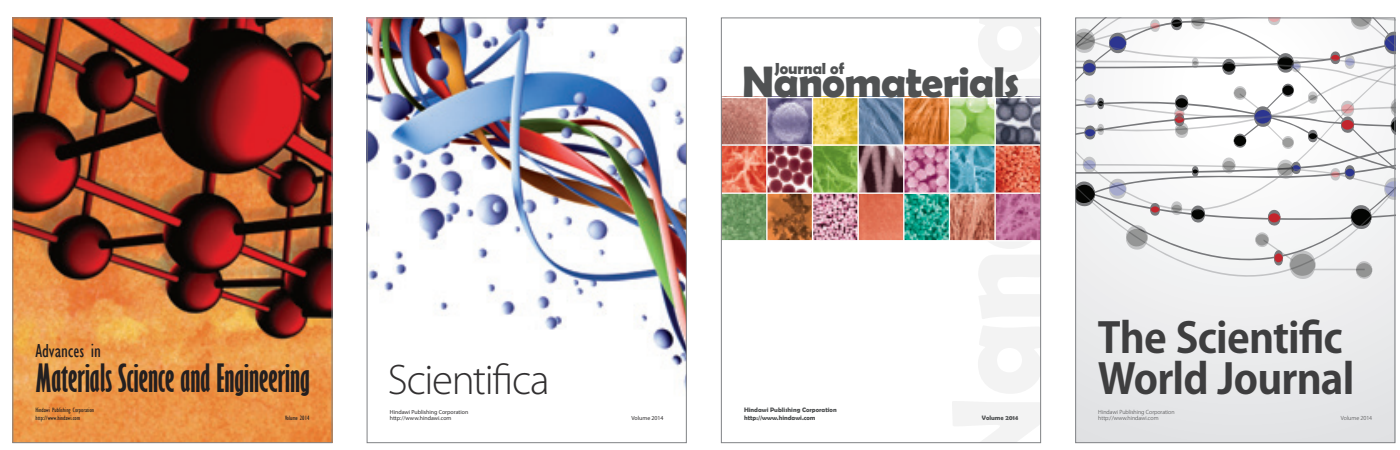

\section{The Scientific World Journal}
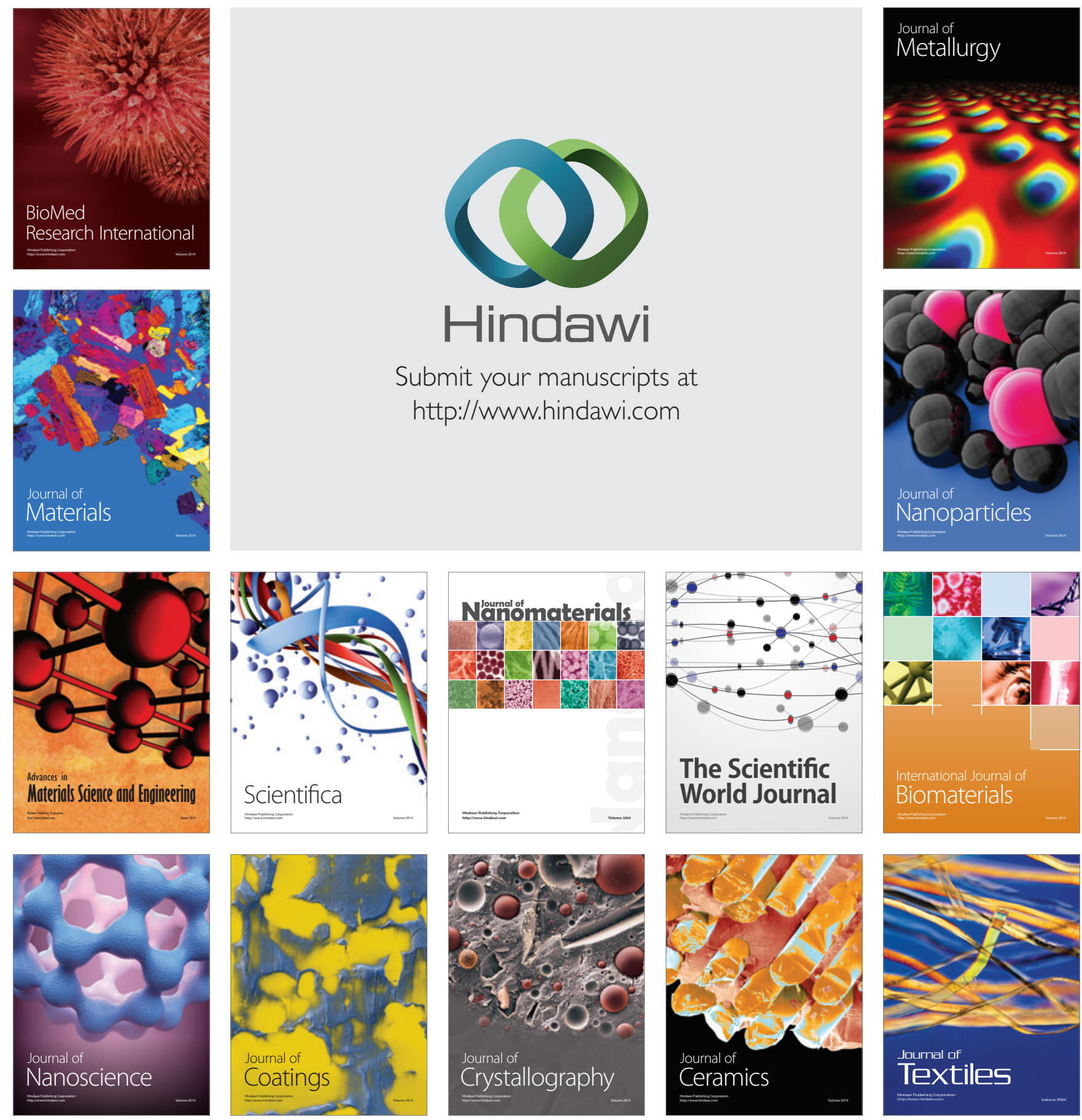